\title{
The continued debate on law and gospel among selected Lutheran scholars within the change agency paradigm
}

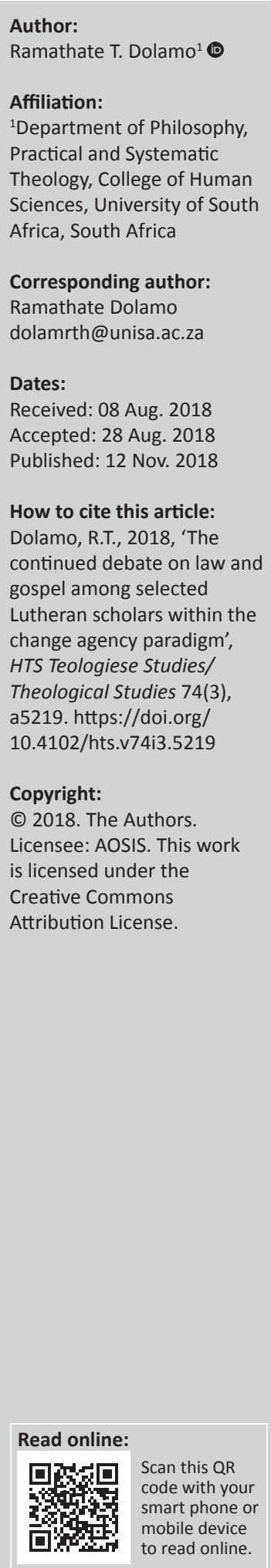

It is interesting that since 1517 when Luther placed the 95 theses on the Wittenberg chapel door, debates ensued with vitality and freshness. Many aspects of the Reformation movement were debated by scholars of all persuasions, including even Roman Catholic theologians. The debates have become contextualised according to regions and countries and the end of the 20 th century and the turn of the 21st have seen the deepening of the debates as scholars wrestle with the issues. This article will confine itself to the debate on the law and gospel among some selected Lutheran scholars with the view to finding some common ground on the topic without stunting further debate and research on the topic. In fact, this article should be able to provoke more thought-provoking discussions on the topic with questions like: What is the relationship between law and gospel if God's Word is both law and gospel? Should we speak of law and gospel or gospel and law? Should we distinguish between law and gospel? What is the use of the gospel and what are the uses of the law? If God's Word is both law and gospel, how should we strike the balance between the two to avoid overemphasising one at the expense of the other within the change agency paradigm?

\section{Introduction}

Luther's twofold use of the law first appeared in 1522 and reached its fruition in 1531 (Nessan 2014:51). According to Nessan (2014):

Employing Luther's two strategies paradigms as an overarching heuristic for interpreting his theology proves fruitful for understanding several apparent contradictions or paradoxes in his thought. Just as it has proven customary and insightful for distinguishing between two uses of the law in Luther's writings, so also we gain clarity about his discussions of righteousness, reason, will and works by recognizing both a civil and theological use of the key concepts. (p. 51)

A number of Lutheran theologians such as Forde, Benne, Tiefel, Nurnberger and Maimela are consulted and their views elicited as to how law and gospel debate could be deepened in such a manner that a positive, meaningful contribution could be made to bring about transformation and change in the world. These scholars have been chosen in such a way that global perspectives are represented. They represent contexts such as South Africa, North America, Germany and Scandinavia. Maimela (1990) says that this debate:

... continues to be revolutionary ... For it pulls the rug out from under those powerful human beings who
would be tempted to arrogate to themselves the power to decide on the ultimate questions of life and
death, something which God alone can do. (p. 151)

Thus, God's Word as law and gospel is an agent of change in society, in church as well as in individuals to make this world a better place to live in. For Maimela (p. 152), The Lutheran doctrine of justification by faith alone underlined the fact that God had accepted all penitent sinners in Christ unconditionally. Let us start by looking at the relationship that exists between law and gospel.

\section{Relationship between law and gospel}

'The Reformation focused on the central aspect of our faith, namely the relationship between human beings as sinners and a God of love and justice' (Nurnberger 2005:99). We are not what we should be in the sight of God and the world in which we live is also not as God intended. To be rescued, God speaks to us through God's Word which is preached as law and gospel. 'The law commands that we should have love and that we should love Jesus Christ, 
but the gospel offers and presents both to us' (Forde 2014:242). For Benne (2014):

The gospel is preceded by the law, by the workings of God as Creator, Lawgiver, Sustainer, and Judge. The God of the Old Testament is active in world history - as well as in our own personal history - before we meet the Christ of the gospel. (p. 249)

In Jesus Christ, God's transformative change and redemption are without conditions.

Nurnberger (2005) gives us a biblical background to the relationship between law and gospel in the following manner. God's covenant with Israel in the Old Testament was conditional. God would provide for and protect Israel on condition that they remained loyal and faithful to God and this law was applicable to the here and now and therefore had nothing to do with the hereafter. However, the New Testament introduces a covenant that is unconditional. In spite of human failings, God would still love humans because Jesus' vicarious suffering and death has released humans from the claws of sin and death (Nurnberger 2005):

Ephesians makes it clear that God's acceptance is not based on our achievements; it is a pure gift of grace. But it does indeed lead us into a new life. God's grace re-creates us in such a way that we do the good works which God himself has prepared for us to do. Now this is a clear case of unconditional, redeeming, transformative acceptance of the unacceptable acceptance comes first, change for the better is a consequence, not a pre-condition. (p. 103)

But this unconditional acceptance did not come without a cost, for this transforming grace is linked to the Cross of Jesus Christ. Through the Cross Jews and gentiles have become one united humanity. The law that favoured one nation as God's chosen race and put conditions for its effectiveness has been suspended and Christ has come to replace it by giving it a correct interpretation versus that of the scribes and Pharisees.

But the Jews having been influenced by Persian religion. Nurnberger (2005) asserts that Judaism moved from solely believing in the salvation as a here and now experience and reality to the belief in the salvation as a future event when God's enemies and the wicked would be condemned and Israel and the righteous would be vindicated. Again, Hellenism with its belief in the immortality of the soul influenced Judaism to believe in the resurrection of the dead, a concept that was carried over into the New Testament. But doing good to avoid condemnation or as an incentive to go to heaven is not a New Testament concept. It is very clear in the New Testament that doing good is not a pre-condition for salvation but a consequence of our new lives in Christ. ' ... If by God's grace we should rise after death, this would not be a resurrection to face judgement, but the gift of a new life ...' (Nurnberger 2005:105).

Nurnberger (2005:106) continues to caution us that this New Testament orientation to salvation has nothing to do with 'pie-in-the-sky' theology. Eschatologically, God's salvation has been made manifest here on earth through God's incarnation in Jesus of Nazareth. God's future is already with us in the Spirit and it impacts our lives and those of others. One may even add that this future encompasses the whole creation as it groans towards the consummation of time and human history ( $\mathrm{Rm} 8: 22$ ). We anticipate our death and resurrection here and in the life to come. Ephesians and Colossians believe that those who accept Christ have eternal life already and those who reject him are condemned already. While on the one hand Matthew and James put great premium on the law of Moses, Titus and Timothy emphasise a need for moral excellence on the other hand. Paul is very definitive that the Decalogue cannot be imposed on the gentiles. That is why he was opposed to Judaizers who demanded that gentiles had to undergo Jewish rituals such as circumcision and observance of kosher foods. Luther is adamant that, 'No law, whether of men or angels may rightfully be imposed upon Christians without their consent, for we are free of all laws' (Wentz 1959:72).

Unfortunately, the gospel message propounded by Paul was altogether lost by the medieval Church, something that sparked the Reformation movement (Maimela 1990:150). The Church had inherited the Roman culture with its legal structures and systems as well as moral precepts. The Church was very powerful and obscenely rich. The authority of the Church was felt everywhere and the bishop of Rome became the embodiment of that power and authority (Mt 16:19). The Pope was regarded as Christ's representative on earth and unto him was also given the keys of heaven and earth. The fear of torture and torment after death was once more brought from the periphery of theology to the centre. 'Purgatory' as a form of punishment was introduced. But there was a way to dodge purgatory. Not just through repentance but also through payment of a fee known as 'indulgences' (cf. Ferguson 2016:142-144). During the Middle Ages, the fear of hell sent people into a frenzy. Convents and monasteries were many and full to capacity and ascetics numerous as the wealthy left behind their riches and donated them to the Church and other charities. 'For all intents and purposes the Pauline gospel of justification by grace accepted in faith, rather than by goods, has been lost'. (Nurnberger 2005:107).

With the Reformation, Luther rediscovered the good news of the gospel of Jesus Christ. Romans 1:17 became the foundation for Luther's theology. God's righteousness was not to condemn sinners but rather was God's free gift of grace (Nurnberger 2005):

It was Christ's own righteousness that God allowed us to share a righteousness that was not achieved by us, but by Christ; a righteousness that did not belong to us, but to Christ, thus an alien righteousness (iustitia aliena). (p. 108)

It was so gratifying that in 1998 a 'Joint Declaration on the Doctrine of Justification' (47-59) was signed by Lutheran and Roman Catholic leaders to find one another on the interpretation of the doctrine. But when one reads through 
the document, one gets a sense that this was a public relations exercise. It was more an attempt at declaring a ceasefire than really finding consensus on the doctrine. Roman Catholics stuck to their episcopal grounding of the Church, while Lutherans maintained their radical understanding of salvation through grace by faith alone. Be that as it may, one concurs fully with Nurnberger (2016) when he says:

Where judgment accuses, acceptance forgives ... where judgment enslaves, acceptance liberates ... and to be liberated means to be empowered to participate in Church and society ... and where judgment condemns, acceptance reassures. (pp. 72-73)

How does a new life in Christ impact on change agency in transforming society? On that note let's look at the intersection of soteriology and ethics in the next section as law and gospel have a direct bearing on salvation and morality.

\section{Soteriology and ethics}

The context of salvation tends to give a generally negative connotation to 'law' and sets the law into opposition to the gospel, whereas the context of ethics presents the same term in a more positive function and in harmony with the gospel. (Tiefel 1967:7)

From a soteriological point of view, Luther is opposed to good works as a means for justification because of the original sin, '... not a single work can be good in us, until our nature and personal being are changed and renewed' (Hillerbrand 1974:151). Accordingly, there is no merit that the sinner can have to be saved. As Luther puts it, 'Only the grace of God, which makes nature pure and new, can sweep it(sin) out' (LW II:152). Luther was not against good works per se but he insisted that those works cannot be used before God as meriting God's favour or blessing. Faith cannot rely on the works of the law. 'God does not condemn or redeem a person for the sake of works, but the works for the sake of the person' (Hillerbrand 1974:151). Once justified by faith, 'good works must follow faith as closely and inseparably as a shadow' (Tiefel 1967:9) for faith cannot be without good works. Good works without faith are good for this temporal life such as wealth, power and friendship; but, one cannot earn eternal life through religious works or works of righteousness (Tiefel 1967):

Thus Luther teaches that works are to be denied as well as that they are indispensable depending on the context. A flat declaration that faith does not perform works, or that faith does not require doing but only believing must always be placed into the proper setting: faith requires no doing in regard to salvation. Luther's forthright and ad hoc style tends to obscure such essential distinctions, yet their necessity is clear. (p. 11)

In the same vein, reason is also condemned by Luther when he says, '... all works and words of God are contrary to reason, and reason, in turn, is contrary to God ...' (Wentz 1959:279). Reason is said to be blind concerning the things of God, for it does not see that people are ill and in need of divine healing and we must therefore 'let go of reason and intellect' (Tappert 1959, 521:8). Reason thinks that it can do
God's will; it joins up with the law and at once it loses its purity, and there is nothing more opposed to faith than this combination of reason and law; therefore, according to Tiefel (1967:12), if one needs to be saved those two must be vanquished. Reason is designated as the arch-enemy of faith or as the bitterest and most harmful enemy of God and therefore reason must be sacrificed, killed and drowned in baptism (Wentz 1959:150). In fact, Nessan (2014:53) quotes Luther who says that reason is a harlot. Luther maintains that, '... it is not the will of God that we should follow either what is in our reason or beyond it; rather we should follow his word alone ...' (Hillerbrand 1974:182). Reason and human will have been rendered useless by Christ who accomplished salvation of the soul (Tiefel 1967):

Human beings do not cooperate with God in the attainment of eternal salvation. To claim a human role, even a minor one, would be an affront to the majesty and glory of God. (p. 15)

But these negative sentiments are somehow qualified because they are expressed in the context of salvation and justification. But in the sphere of ethics reason just like law plays an integral part in the ordering of the world's activities and preservation of outward life and cannot save the sinner from sin and death. Reason is good only for the temporal things and it does have a divine function in the world but not in the salvation of souls. 'Here reason is seen as implanted by God and uncontested by the gospel, a splendid instrument and tool of God' (Tiefel 1967:15). Like Tiefel, Nessan (2014) notices that reason gets a positive valuation when it comes to what he terms civil righteousness or religious righteousness. He quotes from Luther's Works 34:137:

Civil righteousness...is that form of righteousness that individuals perform in relation to their neighbors ... Even nonChristians have the capacity to engage in civil righteousness in service to neighbors in their families, workplaces, and public life. God structures and provides order in daily life through those who live out their roles with responsibility for the care of others as neighbours. (p. 52)

Although this form of righteousness according to Nessan is ascribed a secondary role in Luther's thought, paraphrasing Luther (WA 36, 39: 21-27) Nessan argues that it remains an essential concept for accomplishing God's purposes of protecting and preserving the world. Nessan (2014) continues to elucidate:

It is certainly true that reason is the most important and the higher rank among all things and, in comparison with other things of this life, the best and something divine. It is the inventor and mentor of all the arts, medicines, laws, and whatever wisdom, power, virtue, and glory men possess in this life. By virtue of this fact it ought to be named the essential difference by which man is distinguished from the animals and other things. Holy Scripture also makes it lord over the earth. (pp. 53-54)

After discussing the dialectical tension between law and gospel, one believes that at this juncture, it would be appropriate to look at the uses of the law within the paradigm of change agency from the perspective of some Lutheran scholars. 


\section{Uses of the law}

Initially, the law in Lutheran tradition had only two uses, the theological use and the political one. However, a 'third use' was mooted starting with Philipp Melanchton. Therefore, according to Tiefel (1967:43), the categorisation of first, second and third uses of the law did not originate with Luther.

\section{Theological-political use of the law}

In the sphere of salvation, law always accuses, it convicts and it judges, and this is the theological use of the law. Law as righteousness designates humanity's attempts at selfjustification and it is opposed to Christ. In the sphere of ethics, law as natural law assumes a positive role which is applicable to both church and society. Ecclesiastically, the law can be referred to as 'the law of Christ' or the law of love. It constitutes the sovereign fulfilment of all ethical forms of the law, something that has probably led to the disputed third use of the law. But in general, the law prescribes the good and prohibits evil (Elert 1967:7-13; Maimela 1984:43-46). Tiefel (1967) emphasises that:

The primary and predominant function or 'office` of the law lies in the soteriological context ... it is a relational and existential term which excludes normative ethical considerations. Soteriologically the law reveals man's totally sinful existence over against God. Here the law is a mirror which shows man what he is. By making man aware of sin, causes sin to grow inwardly. The law brings man before the judgment throne, it accuses and frightens, it damns man as its violator. (p. 17)

This function of the law is to lead the sinner to Christ who then kills the the law sin and death and then liberates those under the law, depriving the law of its deadly quality. Luther indicates that "The law only points out this sin and teaches one to recognize it, but the law does not help against sin'. For humans to be redeemed, law and gospel are necessary, although they stand in tension with each other and wrestle with each other as if they are in a wrestling contest. For sure, law and grace cannot co-exist. As Tiefel (1967:22) puts it, 'When Christ brings grace and salvation, He transfers believers from the law to the gospel, from wrath to grace, from sin to righteousness, from death to life'.

Perfect obedience to the law is unattainable for the sinful person. We must love God and our fellow human beings, a standard not attainable. Only Jesus of Nazareth was able to keep the law because besides being fully human, He was also fully divine as the son of God. Jesus' righteousness makes it possible for the unrighteous to be righteous, for no one is regarded righteous unless and until he or she fulfils the law. Ethically, 'The law gives structure, direction, and guidance to human life and it provides necessary discipline and coercion' (Tiefel 1967:30).

Law as divine organising principle guides the civil community through the natural law, identical to the Old Testament, the golden rule and rule of love in general.
The New Testament embraces love(agape) as the ideal ethical rule and natural law is inborn to all humans. The Decalogue teaches us how to relate to both God and neighbor. Old Testament and natural law are applicable to the Church also in a morally guiding relationship. Obedience is of paramount importance but has nothing to do with salvation of the soul, as sufficiently argued above. This use of the law prevents chaos and encourages discipline. For Christians, Moses is not a lawgiver, but Christ is. Moses' laws are exemplary and helpful, but they are not absolute. According to Tiefel (1967:36), for Luther, 'Christian faith expressing itself in love goes beyond all specific demands of the law. And the law finally commands nothing else but love'. The Love Commandment that Luther calls the 'law of Christ' should be regarded as another definitive use of the law and it is inspired by the Holy Spirit. According to Luther (Hillerbrand 1974):

... the gospel teaches that God's law is spiritual and that it is
impossible for human nature to fulfil it; God's Spirit must fulfil it
in us through faith, Romans 8:3-4. (p. 241)

Although Christ is the end of the law, the law must be kept (Mt 5:17). What Christians have been liberated from is the legalistic demands of the law.

\section{Law coerces and disciplines because (Tiefel 1967):}

Men are evil and do not obey the law voluntarily so that they have to be coerced into compliance through the sword, gallows and other punishment. The law restrains men as chains restrain wild animals. Through fear men must be kept from doing what otherwise they do only gladly. (pp. 40-41)

But Christians do not need this civic use of the law because the Holy Spirit enables them to fulfil the law with gladness. Yet Luther is honest enough to acknowledge that although believers have been saved, they are still sinners who would need to be nudged in the direction of Christ from time to time. '... they who live under the law, do not live well, for they do only the works of the law unwillingly and without desire' (Hillerbrand 1974:131). Living in the flesh, Christians also need to be compelled to follow the law. 'Thus the law is to rule over his body and members over the old Adam who always stirs in him, but not over conscience, where only Christ belongs' (Tiefel 1967:42). This statement was obviously directed at the antinomians who believed that because they were saved, there was no need for them to follow the law, something that Paul counteracted when he addressed the laissez faire attitude in the Roman Church. The guiding, teaching and disciplining function is really palpable in the ethics of Luther but he was not convinced by his colleague Melanchton of the necessity for the third use of the law. But what is this third use of the law? Let us turn to this concept.

\section{The third use of the law}

Christians do not need the law, but because they are still human, they require what is called the third use of the law to guide them. They are still sinners; although justified by Christ through faith alone, Christians are simul iustus et peccator. 
Obedience is of paramount importance, but it has nothing to do with salvation of the soul. This use of the law prevents chaos and indiscipline (Rm 13). Tiefel (1967:36) expresses this idea clearly when he says, 'Christian faith expressing itself in love goes beyond all specific demands of the law. And the law itself finally commands nothing else but love'.

According to Tiefel (1967:251), Paul Althaus asserts the notion of the third use of the law, while Ernst Wolf refutes it. Werner Elert and Gerhard Ebeling are also representatives of the opposition to the third use of the law. For Elert (1967:713), law is always accusative, and therefore, arguing for the third use of the law is illegitimate. I agree with Tiefel (1967:252) when saying that in Luther's theology law is always addressed to the old nature, the flesh, while the new person who is in Christ knows nothing of the law:

Law cannot be a manifestation of God's grace, otherwise it would be the gospel. Law is always opposed to the Gospel and the Holy Spirit. With the third use, the law is deprived of its divinely uttered threat of retaliation, and the gospel has its redeeming power ... drained out and it attempts to reduce the plan of salvation as a moralizing tool for the world. The guiding, pedagogical use of the law is negated. (p. 253)

According to Tiefel (1967:254), Ebeling regards the law as an existential category in which the theological interpretation of human existence is concentrated. Law is focused on the reality of fallen human beings. Ebeling 'excludes the normative or guiding function of the law; the knowledge that the law gives is not of the good but only of sin' (Tiefel 1967:254). Tiefel (1967:255) continues to indicate that Ernst Sommerlath treats law and gospel antithetically in that he maintains that where the law speaks the gospel must keep quiet and where the gospel is pronounced the law must shut up. Here the guiding use of the law is easily translated into accusing function. According to Tiefel (1967:255), Sommerlath insists that 'the character of the law as a rule for a righteous life only accentuates its accusing function'. For Sommerlath therefore, there could be no third use of the law. It is argued that there cannot be any doubt that law and gospel are in an irrevocable tension. It is asserted that the third use of the law can never be anything else than a means of justification. A special theological use of the law, it is argued, would mix and abrogate the distinction between law and gospel. According to Tiefel (1967):

The reborn believer is split into a new and old man ... The reborn man insofar as he is the old man, always needs the law, norms, and demands, but the new man lives completely without the law ... To say that the law is a norm for the new man would be to place the law over the gospel and to make a guideline for the new life, the life of faith. (p. 256)

God rules over humans through law and gospel as argued above, but the two cannot be unified. In other words, law and gospel should not be collapsed into each other or be confused with each other. 'When the law speaks, the gospel is silent. When the gospel speaks, the law must hold its peace' (Elert 1967:1). The positive appreciation of the law cannot be denied for God's will is revealed in the Decalogue. According to Tiefel (1967:258), 'God's law had been misunderstood and misused, but in Christ God acted to perfect it for righteousness'.

Tiefel (1967) concludes rightly that all Luther scholars agree on the theological use of the law:

Differentiations in regard to reference of context, however, permit the additional ethical or guiding function of the law without compromising statements concerning salvation. Such differentiations free the interpreters from a systematic position which insists that the soteriological function of the law is definitive. Those distinctions allow two very different complexes of references to be accommodated by the same concept, and, it seems to us they enable a better understanding of Luther's diverse uses of the 'law'. Conversely, the denial of a guiding function of the law for the believers by the former group seems to us to illustrate a tendency in Lutheranism to distort ethics through soteriology. (pp. 261-262)

One of the most productive revisitations of the debate around the relationship between law and gospel comes from Maimela (1984). Here the positive appreciation of the law is expressed without collapsing the distinction between the two concepts. Law as a change agent is regarded as God's tool in creating and sustaining God's creation. To this we now turn.

\section{God's creativity through the law}

One of the most strategic approaches to the relationship between law and gospel in general and the uses of the law in particular is that of Maimela (1984). He argues that the meaning of the two concepts cannot be defined in black and white, and over the years since the Reformation to the present, the debate has become problematic to say the least. He is totally against the mainstream view that humans have nothing to contribute in creation and it is correct that Luther's social writings are replete with pessimism about the capacity of humans to engage in unselfish actions (Herman 2001:260). Maimela's (1984) positive view of the law is accentuated when he says:

More often than not, Barth and Elert tend to talk about law within a framework of human justification before God, and the positive ordering and structuring of life situations in a continuing creation by God are ignored. Yet the divine law, when it is properly understood, cannot be viewed as a foreign instrument or something that is external to human and cultural activities. For God, as the Creator, bring about structures through the law and thereby creates life for the community here and now. In order for these positive and creative aspects of the law to be given full expression, it becomes necessary to pay attention to the social, political and other cosmic creative activities of God where law functions to enhance both the natural and the social life. (pp. 157-158)

Maimela refers to law as divine command. While God's redemptive activity through the gospel is relatively clear, for Maimela, however, that of positive activity through the law is still ambiguous. He poses the question as to whether the law, which he calls the divine command, can be regarded 
as God's instrument of love both in originating and in sustaining creation in its historical development. God's command is God's logos that created everything and sustains everything created. For Maimela, creation and the divine command belong together. God's law should not be equated with the Decalogue, and at the same time there is no universal and immutable natural law that should be regarded as the material content of the divine law. God's law is much broader than the Decalogue because God reveals God's law also through reason, in nature and so on. Each and every culture has its own laws and Luther (Wentz 1959:72) rejected the idea of imposing the Decalogue on non-Jewish communities (Maimela 1984):

Luther argued that the content and function of all laws ... were the same and that differences were matters of divergent interpretations of the natural law which is written in our hearts. (p. 159)

\section{Maimela (1984) insists that:}

Static notions of the law of God should be rejected, because they ignore the fact that the law is always a historical production... laws truly understood are human and historical productions and can therefore not be separated from activities that transform the world. Human beings are not objects of ideals but are also subjects with God in a creative process in which creation is carried towards its completion. (p. 159)

The biblical culture like all human cultures is a human and historical production. Only God is transcended. One problem associated with the immutability of the divine law is that creation is completed and what the law does is to preserve, conserve and sustain God's creation and protects against some alleged threat of chaos. This function of the law must also be understood as creation in the present and God's providential care is itself creativity (Maimela 1984):

Creation and law should never be construed as separate units that must be juxtaposed as if different things are meant; rather, together they constitute the totality of God's originating and sustaining creativity through the word. (p. 161)

Preservation means creation that continues. God is continually creating through preservation and development. 'Creatio continua' is a faith statement, according to Maimela (1984), and he asserts that:

\begin{abstract}
... it is a creedal affirmation of believers' assurance that God is presently creative now, giving life and sustaining it. Because a creedal statement is tied closely to personal involvement and is coloured by believers' experiences, it remains an expression of thanksgiving and praise to God who stands behind human life, showering on it blessings, love and divine goodness. (p. 164)
\end{abstract}

He iterates that our lived experiences contradict God's love for us, and yet in spite of our painful environment, God continues to sustain and preserve us and will continue to sustain God's world after we have ceased to live. Benne (2014:249) speaks of the law as structures that are referred to as orders of creation, mandates, natural orders or places of responsibility in Lutheran circles by which God sustains the world and provides moral contexts within which humans can live. These structures are therefore not static.

\section{The divine commanding as itself a creative activity}

As indicated above, Maimela affirms that God is creatively involved in the dynamics of life-giving activities, through the same divine command, the Logos. According to him, the law is an instrument by which God structures the world; thus, the law is integral to ethics. Creator and creature interrelationship is essential for God does not interrupt from outside creation and creatures are never independent of the Creator. The sustaining creativity of the divine commanding is different in that the latter is done out of nothing (ex nihilo) and the former is a moulding of the creature in the continuing work of creation (creation continua). The law should also be understood as itself a creative activity because of its correlation to creation. In this context, law is 'largely purged from moralistic connotations' (p. 168). 'The divine Word is ... therefore the instrument of creation through which God performs divine works and relates to the world either creatively or redemptively' (p. 174). Maimela (1984) insists that:

We must maintain continuities between divine and human creative activities in this ongoing, unfinished creation of the world because history, or the creation of the world, is not the sole monopoly of a jealous God but is also the creation of human work; for humans are co-agents, co-workers and co-creators within the presence of and through the help of God. (p. 191)

God employs humans in his continuing creative process. God is not a dictator or a tyrant out there controlling developments in the world. Such a God, Maimela (1984:191) maintains, would be demonic and responsible for all the pain and suffering in the world. But since God trusts human beings, they are unfortunately responsible for the aberrations and distortions of God's commanding in the world. At the origination of creation, God did not require any human activity, obviously because humans are not pre-existent but rather are part of God's creation. Yet, with the production of human history, humans have become crucial and pivotal in God's ongoing commanding (Maimela 1984):

Human activity ... continues alongside God's creating and has its meaning in the mutual production of the world within the overall sustaining creativity of God that surrounds, supports, modifies, permits and limits the human acting. (p. 192)

But why do human beings occupy such a unique position in God's plan in contradistinction to other creatures? And why does God still trust humans after the Fall and subsequent failings and blunders? Firstly, the concept of 'imago Dei' is given as a reason (Maimela 1984):

The traditional view argued that humans possess this image of God or uniqueness among creatures because they are endowed with reason, the power of will, religiosity or a supposed spark of 
immortality and other related intelligence which enable them to transform the animal state and realize their purpose in history. (p. 193)

But Maimela immediately draws our attention to Brunner's rebuttal of this traditional view because it deifies human beings. 'Creation of history and civilization do not make humans into the image of God but their creativity presupposes imago Dei which must precede cultural and historical developments' (Maimela 1984:193). The uniqueness of humans in creation lies in their historicalness or historicity. Humans '... create because God's creative power surrounds them, and is made available to them; for they continue to create only because God has not withdrawn this creative power' (p. 196). According to Maimela (1984):

It is when this human dependence upon God's creative power is maintained that human beings can further God's creation. On their merits, they cannot produce God's world, at least not the coming new world. But as repositories of the creative they can, as divine instruments, contribute towards the realization of the coming Kingdom. (p. 196)

Maimela asserts that God has tremendous faith in us and God continually empowers us to create together with God's self. It was in God's plan for humans to become God's assistants in the preserving and protection of creation. It was therefore not accidental. But we do not have inherent powers to recreate because the source for those powers is God. For Maimela (1984), 'The only thing remaining is that human beings should take themselves as seriously as God does' (p. 198) in spite of our imperfections. We have the ability from God to create freely as agents in creation (Maimela 1984):

God creates ex nihilo while human beings are entrusted with the creative power to transform their social surroundings and environment as well as shaping and naming what is given as secondary and existential creators in this mutual production of the world. (p. 199)

For Maimela (1984), this creative Word continues to 'involve, engage, condition and modify human actions as the production of history and the world is being carried out' (p. 199) and:

As long as we remain in the relational context of the divine creativity, we are capable of being co-creators, co-agents and coproducers of history in the freest and most responsible manner possible with God. (p. 200)

\section{Maimela (1984) continues:}

Human beings have been trying to actualize this empowering and enabling creative command through their history by transforming their environment and by creating civilizations and their world, culture and history ... The creative ability to find and name which has been increased by modern revolutionary and technological knowhow, has not only enabled human beings to discover laws of nature and variety of natural resources and foods but also to discover the ever-expanding universe, planets with a whole range of microcosmic and macrocosmic realities yet to be named. The creative victory over the tyranny of nature occurs because the empowerment of human beings, through the creative command (word), to dominate and use the created order is gradually being realized or actualized as humans become involved in the dynamics of the ongoing production of history. (p. 200)

For Maimela, natural disasters, for example, are managed, contained and even tamed by humans in line with their Godgiven mandate to become God's agents in participating in this ongoing creation of the world.

\section{Maimela (1984) continues and states that:}

In addition to discoveries and naming, human beings have been exercising their entrusted lordship and ability to create by transforming the natural order, by creating ever emerging structures, by ordering their world and by a variety of social relationships in society and culture ... they have been able to prosper on earth, to develop civilizations, traditions, all kinds of socio-economic, legal and political institutions, laws and customs, judicial and governmental administrations, all of which seeks to establish and enhance healthy human relationships in a community or society, or between nations. (pp. 200-201)

Second, this unique position of humans in God's creation put them as trustees of God's creation. As human beings, we are accountable to God, and not to ourselves, for what we do and God cannot be indifferent towards our activities as God's managers of creation. God has tasks and responsibilities for us. As Maimela (1984) puts it:

Our accountability follows from the fact that the Creator, by granting us creative ability in continuing creation, has goals and purposes which our willing obedience and active participation in the dynamics of divine creativity should achieve or serve. These purposes include the responsible and meaningful creative caring of the natural order, the responsible ordering and structuring of society and willing cooperation in the production of the world with our Creator as divinely delegated representatives. The fulfilment of these tasks, goals and purposes in our participatory involvement in the creative dynamics of God constitutes our vocation, mission or service as the trustees and stewards of the Creator who has enlisted human service. (p. 202)

As we are grateful for God's creation, we are not to idolise or worship creation because it is finite. Yes, indeed, the natural and social environment are gifts from God but they cannot become objects of worship. We would be surrendering our privileged position in creation if we were to do that. We must also mind the fact that our unique position as stewards is not unlimited. Dominion over creation does not entail domination and exploitation. Sin in the form of greed and capitalism, for example, have contributed to the degeneration of the environment. We must not forget that nature is finite and we as human beings are depended on it and not the other way round. Maimela (1984:206-207) says that in spite of sin and our irresponsibility, God has not let the world be totally destroyed. This is because God is not totally dependent on our willingness to create history. God is not 
dependent on human whim and control. Somehow God has a way of using even those who are not willing to create history for God's purposes. As we speak of our participation in God's creative activity, we find ourselves in the sphere of social righteousness, 'coram hominibus', which must not be equated with the righteousness of faith, 'coram Deo'. God is served through this social righteousness. Maimela (1984) argues therefore that:

This righteousness is no less a holy work than spiritual righteousness. And because this righteousness is attained when God works under the cover of a human mask in concert with the human agent, Luther suggests that it is the Creator's righteousness; for when God's own way of acting is embodied and radiated through us, God's honour is at stake, though we also get rewarded by maintaining our virtue, integrity, honesty and clean conscience before our fellows in acting justly and proving our love to all. (p. 208)

\section{Conclusion}

It must be obvious by the end of this study that a complete agreement on the doctrine of law and gospel among Luther scholars cannot be reached even after 500 years of Reformation. It will be even more difficult for Lutherans and other traditions to see eye to eye on the doctrine. We have intimated above that even the Lutheran-Roman Catholic Joint Declaration signed in 1998 does not honestly deal with the differences between them regarding justification of the sinner by grace alone. What Maimela (1984) has done was to clearly delineate the two concepts of law and gospel and to apportion law its positive role in the ongoing creative activity of God by using human agents, no matter how fallible, in the transformation and preservation of the world. Distinction between the two concepts and functions of both and how they are interlinked are subjects for further debate, perhaps for another 500 years.

\section{Acknowledgements Competing interests}

The author declares that he or she has no financial or personal relationships that may have inappropriately influenced him or her in writing this article.

\section{References}

Benne, R., 2014, 'Law and Gospel, personal and political', Lutheran Quarterly XXVIII, 249-265.

Elert, W., 1967, Law and Gospel, Social Ethics Series 16, Fortress Press, Philadelphia, PA.

Ferguson, S.B., 2016, 'Grace alone: Luther and the Christian Life', in R.C. Sproul \& S.J. Nichols (eds.), The Legacy of Luther, pp. 141-159, Reformation Trust Publishing, Sanford, FL.

Forde, G.O., 2014, 'Law and Gospel in Luther's Hermeneutic', Currents in Theology and Mission 41(1), 240-252.

Herman, S.W., 2001, 'Luther, law, and social Covenants', Lutheran Quarterly X, 257-275.

Hillerbrand, H.J., 1974, Luther's works, Sermons II, vol. 52, Fortress Press, Philadelphia, PA.

Maimela, S.S., 1984, God's creative activity through the Law: A constructive statement toward a theology of social transformation, University of South Africa Press, Pretoria.

Maimela, S.S., 1990, 'Responsibility for the World: Luther's intentions and their effects', Lutherjahrbuch, pp. 147-162, Vandenhoeck \& Ruprecht, Gottingen.

Nessan, C.L., 2014, 'Law, righteousness, reason, will, and works: Civil and theological uses', Currents in Theology and Mission 41(1), 51-56.

Nurnberger, K., 2005, Martin Luther's message for us today, Cluster Publications, Pietermaritzburg.

Nurnberger, K., 2016, Faith in Christ today vol 1. Life in the presence of God, Cluster Publications, Pietermaritzburg.

Tappert, T.G. (ed.), 1959, The Book of Concord: The Confessions of the Evangelical Lutheran Church, Fortress Press, Philadelphia, PA.

Tiefel, H.O., 1967, The ethics of Gospel and Law: Aspects of the Barth - Luther Debate, Yale University, Ph.D 1967, Princeton, NJ.

Wentz, A.R., 1959, Luther's works, word and Sacrament II, vol. 36, Fortress Press, Philadelphia, PA. 